\title{
Kadar Vitamin C Buah Tomat (Lycopersicum esculentum Mill) Tiap Fase Kematangan Berdasar Hari Setelah
} Tanam

Lega Dwi Asta Sari ${ }^{1}$, Riska Surya Ningrum ${ }^{2 *}$, Aisyah Hadi Ramadani ${ }^{3}$, Evi Kurniawati ${ }^{4}$

${ }^{1}$ Program Studi D3 Farmasi, Fakultas Farmasi, Institut Ilmu Kesehatan Bhakti Wiyata, Kediri, Indonesia

${ }^{2}$ Pusat Penelitian Biomaterial, Lembaga Ilmu Pengetahuan Indonesia, Bogor, Indonesia

${ }^{3}$ Program Studi Biologi, Universitas Muhammadiyah Lamongan, Lamongan, Indonesia

${ }^{4}$ Program Studi S1 Farmasi, Fakultas Farmasi, Institut Ilmu Kesehatan Bhakti Wiyata, Kediri, Indonesia

*Corresponding author: riska_suryaningrum17@yahoo.com

Submitted: 4 Juli 2020

Accepted: 5 Januari 2021

Published: 27 April 2021

\begin{abstract}
Background: Tomato (Lycopersicon esculentum Mill.) contains vitamins and minerals which are beneficial for boosting the human immune system. The content of vitamin $C$ in fruit is dynamically affected by a physiological factor during its growing phase and the varieties. Objective: This research evaluated the profile of vitamin $C$ in different maturity phases based on the day after planting as a reference for the best harvest time to obtain optimal vitamin C content. Method: Vitamin C content was examined qualitatively by $\mathrm{KMnO}_{4}, \mathrm{FeCl}_{3}$, and $\mathrm{AgNO}_{3}$ reagents, while the quantitative value was counted by iodometric titration method with 3 replications. One hundred gram of fresh fruits used as a sample in each maturity phase which harvested on the $45^{\text {th }}$ with 3 days interval until $72^{\text {nd }}$ days after planting. Results: Vitamin $C$ was found in each sample and the quantitative test showed that its levels start to increase at 45 until 63, then decreased to 72 days after planting. Tomato sample of $63^{r d}$ days after planting had the highest vitamin C level $(21.29 \mathrm{mg} / 100 \mathrm{~g})$. The fluctuation of vitamin $C$ in tomatoes is influenced by the level of fruit maturity, climate, and environmental conditions during the fruit growing period. Conclusion: Vitamin $C$ of tomatoes reach the optimum level responding to the ripening process and climatic condition during growing season. To get the best intake of vitamin $C$ from tomatoes fresh fruit consumption, our research recommends harvesting the fruits at the $63^{\text {rd }}$ days after planting which are the peak level of vitamin $C$.
\end{abstract}

Keywords: vitamin, ascorbic acid, iodimetric, ripening, days after planting

\begin{abstract}
Abstrak
Pendahuluan: Tomat (Lycopersicon esculentum Mill.) mengandung beragam vitamin dan mineral yang bermanfaat untuk meningkatkan sistem imun tubuh manusia. Vitamin $\mathrm{C}$ merupakan salah satu antioksidan yang berharga dalam buah ini. Kandungan vitamin $\mathrm{C}$ pada buah tomat segar secara dinamis dipengaruhi oleh faktor fisiologis selama fase pertumbuhannya. Tujuan: Penelitian ini bertujuan mengevaluasi profil kadar vitamin $\mathrm{C}$ pada tiap fase kematangan buah yang diukur berdasar hari setelah tanam sebagai acuan waktu panen yang tepat untuk mendaptkan kadar vitamin $\mathrm{C}$ yang optimal. Metode: Evaluasi vitamin C dilakukan secara kualitatif menggunakan reagen $\mathrm{KMnO}_{4}, \mathrm{FeCl}_{3}$, dan $\mathrm{AgNO}_{3}$, sedangkan nilai kuantitatif diukur dengan metode titrasi iodimetri untuk tiga replikasi. Buah tomat segar sebanyak $100 \mathrm{~g}$ digunakan sebagai sampel, untuk tiap fase kematangan dipanen pada hari ke 45 dengan interval 3 hari hingga 72 hari setelah tanam. Hasil: Uji kualitatif mengindikasikan keberadaan vitamin $\mathrm{C}$ pada tiap sampel penelitian. Hasil uji kuantiatif menunjukkan bahwa kadar vitamin $\mathrm{C}$ mulai meningkat pada 45 hingga 63 hari setelah tanam, kemudian menurun hingga 72 hari setelah tanam. Sampel tomat yang diambil pada 63 hari setelah tanam mengandung vitamin $C$ tertinggi sebesar $21,29 \mathrm{mg} / 100 \mathrm{~g}$. Fluktuasi vitamin $\mathrm{C}$ pada tomat segar dipengaruhi oleh tingkat kematangan buah dan faktor lain seperti iklim dan kondisi lingkungan selama masa pertumbuhan buah. Kesimpulan: Vitamin $\mathrm{C}$ buah tomat segar mencapai kadar optimum merespon proses pematangan dan kondisi iklim selama masa pertumbuhannya. Untuk mendapatkan asupan vitamin $\mathrm{C}$ terbaik dari
\end{abstract}


konsumsi buah tomat segar, direkomendasikan agar buah tomat dipanen pada 63 hari setelah tanam yang menunjukkan puncak kadar vitamin $\mathrm{C}$.

Kata kunci: vitamin, asam askorbat, iodimetri, pematangan, hari setelah tanam

\section{PENDAHULUAN}

Tomat diklasifikasikan sebagai buah dan sayuran yang mudah dibudidayakan di berbagai wilayah Indonesia. Tingginya kandungan air, daging buah yang segar, kulit berwarna kuning kemerahan, dengan rasa manis asam merupakan karakteristik yang paling menarik konsumen. Pada tahun 2013, produksi tomat Indonesia mencapai 992.780 ton, namun tahun 2014 dan 2015 mengalami penruunan sekitar 7,74\% dan $4,17 \%$ (Taufik, 2015). Penurunan produksi tomat disebabkan oleh berkurangnya lahan pertanian yang subur dan perbedaan waktu panen. Tomat yang dipanen sebelum matang ataupun yang mengalami penundaan waktu panen akan menghasilkan mutu buah yang kurang baik.

Mutu tomat dapat dilihat dari bobot buah dan kandungan kimia dalam buah. Fakhrunnisa dkk. (2018) membuktikan bahwa pada tomat cherry dan tomat beef, semakin bertambah waktu panen maka semakin menurun bobot buah tomat. Kandungan kimia dalam $100 \mathrm{~g}$ buah tomat adalah 3,6 $\mathrm{g}$ karbohidrat, $1 \mathrm{~g}$ protein, $0,2 \mathrm{~g}$ lemak, $10 \mathrm{~g}$ kalsium, $16 \mathrm{mg}$ fosfor, $0,6 \mathrm{mg}$ zat besi, $1700 \mathrm{IU}$ vitamin $\mathrm{A}, 0,1 \mathrm{mg}$ vitamin $\mathrm{B}$, dan $21 \mathrm{mg}$ vitamin C (Dobrin dkk., 2019)

Vitamin $\mathrm{C}$ atau yang dikenal dengan nama asam askorbat merupakan vitamin yang mudah larut dalam air, berbentuk kristal putih, dan mudah teroksidasi jika terpapar udara. Vitamin $\mathrm{C}$ memiliki peranan yang sangat penting bagi tubuh, yaitu sebagai antioksidan alami, antikanker, menjaga kesehatan gigi dan gusi, serta menjaga daya tahan tubuh (Tareen dkk., 2015). Surbakti \& Berawi (2016) mengemukakan bahwa konsumsi tomat dapat mencegah penuaan. Bahkan penelitian terkini vitamin $\mathrm{C}$ digunakan sebagai terapi meningkatkan imunitas dan pereduksi badai sitokin pada pasien Covid-19, serta virusidal terhadap virus influenza dan herpes (Boretti \& Banik, 2020; Biancatelli dkk., 2020; Susilo dkk., 2020).

Asam askorbat sangat penting bagi tubuh. Asupan minimal asam askorbat atau vitamin $\mathrm{C}$ bagi orang usia produktif (16 - 64 tahun) sebanyak $75 \mathrm{mg}$ - $90 \mathrm{mg}$ per hari, anak-anak $35 \mathrm{mg} / \mathrm{hari}$, ibu hamil $70 \mathrm{mg} /$ hari dan ibu menyusui 95 mg/hari (Rosmainar dkk., 2018). Guna memenuhi kebutuhan minimal tersebut, penelitian yang mengkaji bagaimana mendapatkan asam askorbat secara optimal dalam buah tomat segar sangat diperlukan.
Beberapa faktor yang dapat mempengaruhi kadar vitamin $C$ pada tumbuhan antara lain adalah kondisi sebelum dan setelah panen (Jones dkk., 2015), temperatur (El-Ishaq \& Obirinakem, 2015), teknik penyimpanan (Galani dkk., 2017), lama penyimpanan (Bieniasz dkk., 2017), kadar air (Wei dkk., 2017; Nemeskéri dkk., 2019) dan tingkat kematangan buah (Rahman dkk., 2015; Ernest dkk., 2017).

Pematangan buah merupakan proses fisiologis yang dipengaruhi oleh metabolisme tumbuhan diindikasikan dengan perubahan warna, tekstur, rasa, dan aroma buah (Valšíková-Frey dkk., 2018). Pada penelitian ini akan dilakukan analisis kadar vitamin $\mathrm{C}$ pada buah tomat berdasarkan tingkat kematangan yang diukur dari hari setelah tanam (HST) dan faktor iklim lingkungan meliputi ketinggian tempat lokasi penanaman, $\mathrm{pH}$ tanah, kelembaban tanah, kelembaban udara, jumlah hari hujan, intensitas hujan, dan intensitas pencahayaan yang mempengaruhinya. Metode yang digunakan dalam penentuan kadar vitamin $\mathrm{C}$ adalah metode titrasi iodimetri.

Hasil penelitian ini akan dapat memberikan pengetahuan tentang waktu yang tepat untuk memanen buah tomat sehingga diperoleh buah tomat dengan kandungan vitamin $\mathrm{C}$ yang optimal. Pengetahuan tentang pemilihan waktu panen yang tepat juga dapat mencegah terjadinya kerugian pemasaran dan meningkatkan nilai jual buah tomat, baik di dalam maupun luar negeri. Pada penelitian sebelumnya, kajian kadar vitamin $\mathrm{C}$ dikaitkan dengan perbedaan fase kematangan (mentah, matang, dan lewat matang). Pada penelitian ini, perbedaan fase kematangan dikaji lebih mendalam melalui variasi hari setelah tanam (HST) untuk mengetahui secara detil hari ke berapa saat panen yang tepat untuk buah tomat.

\section{BAHAN DAN METODE Bahan}

Benih tomat sebagai sampel dalam penelitin ini adalah varietas servo $F 1$ yang unggul dataran rendah dan memiliki produktivitas tinggi serta tahan terhadap virus Gemini (Hapsari dkk., 2017). Benih tomat diperoleh dari perkebunan tomat di Jombang. Bahan untuk mengukur kandungan vitamin $\mathrm{C}$ meliputi larutan $\mathrm{KMnO}_{4} 1 \%, \mathrm{FeCl}_{3} 1 \%$, dan $\mathrm{AgNO}_{3} 1 \%$ sebagai reagen 
uji kualitatif. Uji kuantitatif membutuhkan larutan $\mathrm{KIO}_{3}$ $0,01 \mathrm{~N}, \mathrm{KI} 10 \%, \mathrm{H}_{2} \mathrm{SO}_{4} 10 \%, \mathrm{NaHCO}_{3} 1 \%, \mathrm{Na}_{2} \mathrm{~S}_{2} \mathrm{O}_{3}$ $0,01 \mathrm{~N}$, amilum $1 \%$, dan air suling.

Alat

Beaker glass, erlemneyer, neraca analitik, blender, gelas ukur, pipet volume, pipet tetes, dan seperangkat alat titrasi.

Metode

\section{Preparasi sampel}

Sampel buah tomat diperoleh dari buah segar yang dipetik langsung dari pohon. Benih disemai dan ditanam di wilayah Mojo, Kediri tanpa intervensi perlakuan khusus yang artinya dibiarkan tumbuh secara alami. Proses penyemaian hingga panen dilakukan mulai 28 Maret hingga 5 Juni 2018. Penentuan waktu panen dihitung dari hari setelah tanam (HST) yaitu dimulai setelah benih disemai (Pramono, 2016).

Tomat untuk sampel dipanen setelah HST-45 hingga HST-72 dengan interval 3 hari. Analisis vitamin C dilakukan pada $100 \mathrm{~g}$ buah segar dari setiap waktu panen. Sebanyak $100 \mathrm{~g}$ buah tomat tersebut diblender, lalu diambil filtratnya dengan cara disaring menggunakan kassa steril. Filtrat tomat yang dihasilkan digunakan sebagai bahan uji kualitatif dan kuantitatif.

\section{Analisis kualitatif metode reaksi warna}

Prinsip dari tes ini adalah perubahan warna pada larutan sampel yang membuktikan kandungan vitamin C dalam buah.

\section{Reaksi warna dengan larutan $\mathrm{KMnO}_{4} 1 \%$}

Filtrat sampel tomat sebanyak $1 \mathrm{~mL}$ direaksikan dengan $10 \mathrm{~mL} \mathrm{KMnO}_{4} 1 \%$ dan $4 \mathrm{~mL}$ air suling. Keberadaan asam askorbat pada buah ditandai dengan perubahan warna larutan menjadi coklat.

\section{Reaksi warna dengan larutan $\mathrm{FeCl}_{3} \mathbf{1 \%}$}

Filtrat sampel tomat sebanyak $1 \mathrm{~mL}$ direaksikan dengan $4 \mathrm{~mL} \mathrm{NaHCO} 31 \%, 10 \mathrm{~mL} \mathrm{FeCl}_{3} 1 \%$, dan $4 \mathrm{~mL}$ air suling. Kandungan asam askorbat atau vitamin $\mathrm{C}$ dibuktikan dengan perubahan waran ungu pada sampel.

\section{Reaksi warna dengan larutan $\mathrm{AgNO}_{3} 1 \%$}

Dipipet $1 \mathrm{~mL}$ filtrat sampel tomat segar direaksikan dengan $10 \mathrm{~mL} \mathrm{AgNO}_{3} 1 \%$ dan $4 \mathrm{~mL}$ air suling. Hasil positif yang menandakan adanya vitamin $\mathrm{C}$ dalam buah ditunjukkan oleh endapan berwarna hitam.

\section{Analisis kuantitatif metode titrasi}

Kuantifikasi kadar vitamin $\mathrm{C}$ diperiksa dengan metode titrasi iodimetri menggunakan prinsip reaksi redoks yang melibatkan oksidator $\left(\mathrm{I}_{2}\right)$ dan reduktor (Vitamin C) (Pathy, 2018). Semua asam askorbat bereaksi dengan iodium menjadi asam dehidroaskorbat. Kadar ditentukan oleh volume larutan titran $0,01 \mathrm{~N}$ dan
$1 \%$ pati sebagai indikator. Volume $\mathrm{I}_{2}$ yang digunakan berbanding linear dengan kadar vitamin C. Proses titrasi iodimetri terdiri dari 3 tahap: (1) pembakuan larutan $\mathrm{Na}_{2} \mathrm{~S}_{2} \mathrm{O}_{3}$ dengan $\mathrm{KIO}_{3}$, (2) pembakuan larutan $\mathrm{I}_{2}$ dengan $\mathrm{Na}_{2} \mathrm{~S}_{2} \mathrm{O}_{3}$, dan (3) titrasi filtrat sampel dengan $\mathrm{I}_{2}$.

\section{Pembakuan $\mathrm{Na}_{2} \mathrm{~S}_{2} \mathrm{O}_{3}$ dengan $\mathrm{KIO}_{3} 0,01 \mathrm{~N}$}

$\mathrm{KIO}_{3}$ 0,01 N sebanyak $10 \mathrm{~mL}, 5 \mathrm{ml}$ larutan $\mathrm{KI} 10 \%$, dan $2 \mathrm{~mL}$ larutan $\mathrm{H}_{2} \mathrm{SO}_{4} \quad 10 \%$ direaksikan dalam erlenmeyer lalu dititrasi dengan larutan $\mathrm{Na}_{2} \mathrm{~S}_{2} \mathrm{O}_{3}$ hingga berwarna kuning muda. Setelah itu ditambahkan beberapa tetes amilum $1 \%$ dan dititrasi dengan $\mathrm{Na}_{2} \mathrm{~S}_{2} \mathrm{O}_{3}$ hingga warna biru hilang.

Penghitungan standar normalitas $\mathrm{Na}_{2} \mathrm{~S}_{2} \mathrm{O}_{3}$ sesuai dengan rumus sebagai berikut (Asmara, 2016).

$$
\begin{aligned}
& \mathrm{V}_{1} \times \mathrm{N}_{1}\left(\mathrm{Na}_{2} \mathrm{~S}_{2} \mathrm{O}_{3}\right)=\mathrm{V}_{2} \times \mathrm{N}_{2}\left(\mathrm{KIO}_{3}\right) \\
& \mathrm{V} 1: \text { rerata volume } \mathrm{Na}_{2} \mathrm{~S}_{2} \mathrm{O}_{3}(\mathrm{~mL}) \\
& \mathrm{N} 1: \text { normalitas } \mathrm{Na}_{2} \mathrm{~S}_{2} \mathrm{O}_{3}(\mathrm{~N}) \\
& \mathrm{V} 2: \text { rerata volume } \mathrm{KIO}_{3}(\mathrm{~mL}) \\
& \mathrm{N} 2: \text { normalitas } \mathrm{KIO}_{3}(\mathrm{~N})
\end{aligned}
$$

\section{Pembakuan $\mathrm{I}_{2}$ dengan $\mathrm{Na}_{2} \mathrm{~S}_{2} \mathrm{O}_{3}$}

$\mathrm{Na}_{2} \mathrm{~S}_{2} \mathrm{O}_{3}$ sebanyak $10 \mathrm{~mL}$ hasil pembakuan dan 3 tetes amilum $1 \%$ dimasukkan ke dalam erlenmeyer lalu dititrasi dengan $\mathrm{I}_{2}$ hingga berwarna biru tua konstan. Standar normalitas $\mathrm{I} 2$ ditentukan dengan rumus sebagai berikut: (Asmara, 2016).

$$
\begin{aligned}
& \mathrm{V}_{1} \times \mathrm{N}_{1}\left(\mathrm{I}_{2}\right)=\mathrm{V}_{2} \times \mathrm{N}_{2}\left(\mathrm{Na}_{2} \mathrm{~S}_{2} \mathrm{O}_{3}\right) \\
& \mathrm{V} 1: \text { rerata volume } \mathrm{I}_{2}(\mathrm{~mL}) \\
& \mathrm{N} 1: \text { normalitas } \mathrm{I}_{2}(\mathrm{~N}) \\
& \mathrm{V} 2: \text { rerata volume } \mathrm{Na}_{2} \mathrm{~S}_{2} \mathrm{O}_{3}(\mathrm{~mL}) \\
& \mathrm{N} 2: \text { normalitas } \mathrm{Na}_{2} \mathrm{~S}_{2} \mathrm{O}_{3}(\mathrm{~N})
\end{aligned}
$$

\section{Penetapan kadar vitamin $\mathrm{C}$}

Filtrat sampel sebanyak $10 \mathrm{~mL}$ dimasukkan ke dalam erlenmeyer, kemudian ditambahkan 6 tetes larutan amilum $1 \%$ dan dititrasi dengan larutan $\mathrm{I}_{2}$ standar hingga berwarna biru. Penghitungan kadar vitamin C dihitung sesuai rumus persamaan titrasi (Ernest dkk., 2017; Duma dkk., 2015).

\section{Pengamatan kondisi iklim}

Kondisi Iklim saat menanam tomat dipelajari efeknya terhadap kandungan vitamin $\mathrm{C}$ dalam buah segar. Parameter iklim yang diukur meliputi ketinggian tempat lokasi penanaman, $\mathrm{pH}$ tanah, kelembaban tanah, kelembaban udara, jumlah hari hujan, intensitas hujan, dan intensitas pencahayaan. Data tersebut diambil setiap hari dan dirata-rata setiap bulannya. Cuaca, Jumlah hari hujan, dan intensitas cahaya diambil dari referensi BPS Kabupaten Kediri, (2018) dan website BMKG. Parameter lainnya diukur secara langsung di lapangan setiap pagi dan sore dengan tiga kali ulangan. 


\section{Analisis data}

Profil kadar vitamin $\mathrm{C}$ dalam tomat servo segar disajikan berupa kurva yang menunjukkan hubungan antara kadar vitamin $\mathrm{C}$ dengan tingkat kematangan buah. Pengaruh hari setelah penanaman dievaluasi menggunakan analisis varian (ANOVA) selanjutnya nilai rata-rata diuji oleh Duncan. Uji ini menentukan waktu panen optimal diukur dari HST untuk mendapatkan kandungan vitamin $\mathrm{C}$ terbaik dalam buah segar Tomat. Korelasi faktor iklim terhadap kandungan vitamin $\mathrm{C}$ dihitung dari uji regresi pada tingkat signifikansi 95\% (IBM SPSS). Uji regresi menunjukkan apakah faktor iklim saat masa tanam hingga panen memberikan dampak pada kandungan vitamin $\mathrm{C}$.

\section{HASIL DAN PEMBAHASAN}

Hasil uji kualitatif vitamin $\mathrm{C}$ pada buah tomat HST ke-45 hingga ke-72 (Tabel 1) menunjukkan hasil yang positif, baik dengan pereaksi $\mathrm{KMnO}_{4}, \mathrm{FeCl}_{3}$, maupun $\mathrm{AgNO}_{3}$. Hasil positif adanya vitamin $\mathrm{C}$ melalui uji dengan pereaksi $\mathrm{KMnO}_{4}$ ditandai dengan perubahan warna menjadi coklat pada larutan sampel. Pada suasana asam, vitamin $\mathrm{C}$ akan dioksidasi oleh ion permanganat $\left(\mathrm{MnO}_{4}{ }^{-}\right)$sehingga melepaskan ion $\mathrm{H}^{+}$dan menjadi asam dehidroaskorbat (Zanini dkk., 2018). Oksidasi tersebut yang menyebabkan warna coklat dengan persamaan reaksi sebagai berikut:

$$
\begin{gathered}
5 \mathrm{C}_{6} \mathrm{H}_{8} \mathrm{O}_{6}+2 \mathrm{MnO}_{4}^{-}+16 \mathrm{H}^{+} \rightarrow 5 \mathrm{C}_{6} \mathrm{H}_{6} \mathrm{O} 6+2 \mathrm{Mn}^{2+}+ \\
10 \mathrm{H}^{+}+8 \mathrm{H}_{2} \mathrm{O}
\end{gathered}
$$

Tabel 1. Hasil uji kualitatif dan kuantitatif kadar vitamin $\mathrm{C}$ buah tomat segar varietas servo pada tiap HST.

\begin{tabular}{cccccc}
\hline \multirow{2}{*}{$\mathrm{HST}$} & \multicolumn{3}{c}{ Uji kualitatif } & Uji kuantitatif Vitamin C (mg/100g) \\
\cline { 2 - 4 } & $\mathrm{KMnO}_{4} 1 \%$ & $\mathrm{FeCl}_{3} 1 \%$ & $\mathrm{AgNO}_{3} 1 \%$ & \\
\hline 45 & + & + & + & + & $8,03 \pm 0,08^{\mathrm{a}}$ \\
48 & + & + & + & $9,31 \pm 0,20^{\mathrm{b}}$ \\
51 & + & + & + & $10,05 \pm 0,02^{\mathrm{bc}}$ \\
54 & + & + & + & $12,83 \pm 0,05^{\mathrm{cd}}$ \\
57 & + & + & + & $15,01 \pm 0,01^{\mathrm{e}}$ \\
60 & + & + & + & $18,74 \pm 0,07^{\mathrm{fg}}$ \\
63 & + & + & + & $21,29 \pm 0,08^{\mathrm{h}}$ \\
66 & + & + & + & $20,32 \pm 0,04^{\mathrm{i}}$ \\
69 & + & + & + & $17,62 \pm 0,14^{\mathrm{ef}}$ \\
72 & + & + & + & $15,80 \pm 0,02^{\mathrm{de}}$ \\
\hline \multicolumn{2}{l}{ Rerata diikuti huruf yang sama tidak berbeda nyata menurut uji jarak berganda Duncan taraf 5\% }
\end{tabular}

Pada uji kualitatif vitamin C menggunakan pereaksi $\mathrm{FeCl}_{3}$, hasil positif ditandai adanya perubahan warna menjadi ungu saat larutan $\mathrm{FeCl}_{3}$ direaksikan dengan sampel dan $\mathrm{NaHCO}_{3}$. Pada reaksi ini vitamin $\mathrm{C}$ akan mengalami oksidasi menjadi asam dehidroaskorbat dan ion besi (III) pada $\mathrm{FeCl}_{3}$ akan mengalami reduksi menjadi ion besi (II) (Risnayanti dkk., 2015). Reaksi redoks antara vitamin $\mathrm{C}$ dan ion Fe hanya dapat terjadi pada suasana basa atau netral (Dewhirst \& Fry, 2018) sehingga sebelum direaksikan dengan $\mathrm{FeCl}_{3}$, ke dalam sampel perlu ditambahkan $\mathrm{NaHCO}_{3}$ yang berfungsi sebagai pemberi suasana basa.

Hasil positif pada uji kualitatif menggunakan larutan $\mathrm{AgNO}_{3}$ menghasilkan endapan hitam. Endapan hitam terbentuk akibat terjadinya reaksi reduksi $\mathrm{Ag}^{+}$dari $\mathrm{AgNO}_{3}$ menjadi Ag yang berwarna hitam, sedangkan asam askorbat akan mengalami oksidasi menjadi asam dihidroaskorbat dengan persamaan reaksi sebagai berikut:

$$
\mathrm{C}_{6} \mathrm{H}_{8} \mathrm{O}_{6}+2 \mathrm{Ag}^{+} \rightarrow \mathrm{C}_{6} \mathrm{H}_{6} \mathrm{O}_{6}+2 \mathrm{H}^{+}+2 \mathrm{Ag}
$$

Penentapan kadar vitamin $\mathrm{C}$ pada buah tomat HST ke 45 hingga HST ke 72 dilakukan menggunakan metode titrasi iodimetri. Prinsip dari titrasi iodimetri adalah zat pereduksi (vitamin C) langsung dioksidasi oleh larutan baku iodium $\left(\mathrm{I}_{2}\right)$, titik akhir titrasi dapat ditentukan dengan bantuan indikator amilum. Persamaan reaksi pada titrasi iodimetri (Damayanti \& Kurniawati, 2017) adalah sebagai berikut:

$$
\begin{aligned}
\mathrm{KIO}_{3}(\mathrm{aq})+6 \mathrm{H}^{+}(\mathrm{aq})+5 \mathrm{I}^{-}(\mathrm{aq}) \rightarrow 3 \mathrm{I}_{2}(\mathrm{aq})+3 \mathrm{H}_{2} \mathrm{O}(\mathrm{l})+ \\
\mathrm{K}^{+}(\mathrm{aq})(1) \\
\mathrm{C}_{6} \mathrm{H}_{8} \mathrm{O}_{6}(\mathrm{aq})+\mathrm{I}_{2}(\mathrm{aq}) \rightarrow \mathrm{C}_{6} \mathrm{H}_{6} \mathrm{O}_{6}(\mathrm{aq})+2 \mathrm{I}^{-}(\mathrm{aq})+2 \mathrm{H}^{+}
\end{aligned}
$$

$\mathrm{I}_{2}(\mathrm{aq})+\mathrm{S}_{2} \mathrm{O}_{3}{ }^{2-}(\mathrm{aq}) \rightarrow 2 \mathrm{I}^{-}(\mathrm{aq})+\mathrm{S}_{2} \mathrm{O}_{6}{ }^{2-}(\mathrm{aq})$ (3)

Normalitas $\mathrm{Na}_{2} \mathrm{~S}_{2} \mathrm{O}_{3}$ yang didapatkan dari pembakuan dengan larutan $\mathrm{KIO}_{3}$ adalah 0,0094 N sedangkan normalitas $\mathrm{I}_{2}$ hasil pembakuan dengan larutan $\mathrm{NaS}_{2} \mathrm{~S}_{2} \mathrm{O}_{3}$ adalah $0,0093 \mathrm{~N}$. Pada proses titrasi sampel menggunakan larutan $\mathrm{I}_{2}$, kelebihan iodin akan dideteksi oleh amilum yang ditandai dengan berubahnya warna larutan menjadi biru lembayung (Pathy, 2018). Volume iod yang dibutuhkan untuk titrasi sebanding dengan kadar vitamin C. Semakin besar volume iodin yang diperlukan untuk titrasi maka semakin besar pula kadar vitamin $\mathrm{C}$ dalam sampel. 
Kadar vitamin $\mathrm{C}$ dalam buah tomat HST ke 45 hingga HST ke 63 mengalami kenaikan, kemudian mengalami penurunan hingga HST ke 72. Kadar vitamin C tertinggi didapatkan pada buah tomat HST ke 63, yaitu $21,29 \mathrm{mg} / 100 \mathrm{~g}$. Hasil uji statistik dengan anova menunjukan $\mathrm{p}=0,00<0,05$, membuktikan bahwa kadar vitamin $\mathrm{C}$ dipengaruhi oleh tingkat kematangan buah. Pengaruh kematangan buah terhadap kadar vitamin $\mathrm{C}$ sebesar $66 \%(\mathrm{R}-\mathrm{Sq}=66 \%)($ Gambar 1$)$. Selebihnya $34 \%$ dipengaruhi oleh faktor lainnya. Tingkat kematangan buah di HST ke-57, 63, dan 66 bersadarkan uji lanjutan Duncan memiliki rerata kadar vitamin C yang berbeda dengan HST lainnya (Tabel 1). Hal ini menandakan bahwa HST tersebut merupakan waktu panen tomat varietas servo F1 yang tepat untuk mendapatkan kadar vitamin $\mathrm{C}$ yang optimal.



Gambar 1. Kandungan vitamin C pada buah tomat segar varietas servo

Tomat yang matang memiliki kadar vitamin $\mathrm{C}$ yang lebih tinggi dibandingkan yang mentah ataupun lewat matang. Hal ini disebabkan oleh meningkatnya kadar gula pada buah yang lewat matang sehingga kadar vitamin C akan berkurang (Rahman dkk., 2015) sedangkan pada keadaan mentah, kemampuan tumbuhan dalam melakukan biosintetik vitamin $\mathrm{C}$ masih rendah (Valšíková-Frey dkk., 2018). Buah terlewat matang terkait dengan pelapasan hormon etilen yang mengaktifkan gen transkripsi untuk sintesis enzim akan menon-aktifkan aktivitas vitamin. Rendahnya kadar vitamin $C$ dapat juga disebabkan adanya manifestasi antioksidan untuk memperbaiki jaringan-jaringan yang rusak akibat meningkatknya kadar radikal bebas dalam sel tumbuhan (Devi dkk., 2016). Valšíková-Frey dkk., (2018) juga melaporkan bahwa kadar vitamin C pada buah tomat dipengaruhi oleh faktor kondisi iklim dan lingkungan, perlakuan pasca panen, temperatur, gas etilen, dan asupan oksigen.
Profil kadar vitamin $\mathrm{C}$ pada tomat juga dijumpai pada sebagian besar buah-buahan lain, seperti mangga gadung dan mangga golek (Rahman dkk., 2015), anggur, lemon, papaya, jeruk, dan jambu mete (Ernest dkk., 2017). Kadar vitamin C tertinggi didapatkan pada buah yang matang. Profil tersebut tidak terjadi pada buah kiwi (Zhang dkk., 2018), paw-paw (Ernest dkk., 2017), dan peach (Fenech dkk., 2019). Kadar vitamin C tertinggi terkandung pada buah yang masih mentah.

Berdasarkan hasil penelitian Risnayanti dkk., (2015) faktor iklim dan kondisi lingkungan tempat tumbuh mempengaruhi kandungan vitamin dalam buah segar. Untuk itu, penelitian ini juga menganalisis bagaimana pola hubungan faktor iklim dengan kandungan vitamin $\mathrm{C}$ pada buah tomat. Parameter kondisi iklim yang diukur meliputi ketinggian tempat (altitudinal), pH tanah, kelembaban udara, kelembaban tanah, cuaca, hari hujan, intensitas hujan, dan intensitas cahaya (Tabel 2). 
Tabel 2. Karakteristik kondisi iklim dan lingkungan selama masa penananam hingga panen

\begin{tabular}{ccccc}
\hline Parameter & Maret & April & Mei & Juni \\
\hline Altitudinal (mdpl) & & & 374 & \\
pH tanah & 7,10 & 7,00 & 7,00 & 7,01 \\
kelembaban tanah (\%rh) & 78,00 & 80,00 & 75,00 & 72,00 \\
kelembaban udara (\%rh) & 86,00 & 88,00 & 78,00 & 76,00 \\
iklim* & hujan & hujan & transisi & kemarau \\
hari hujan (hari)* & 12 & 13 & 4 & 2 \\
intensitas hujan (mm)* & 296,0 & 249,0 & 24,0 & 9,0 \\
intensitas cahaya (Lux) & 508,5 & 532,7 & 628,5 & 723,6 \\
\hline *BPS Kabupaten Kediri (2018) & & &
\end{tabular}

Hasil pengukuran paremeter menunjukkan bahwa penanaman tomat pada penelitian ini dilakukan selama akhir musim hujan hingga awal musim kemarau. Tanaman tomat diawal pertumbuhannya mendapat suplai air yang baik dari intensitas hujan cukup tinggi. Suplai air yang melimpah diperlukan untuk menginduksi perkecambahan biji tomat. Kontak dengan air yang mengalir juga baik untuk menghilangkan lendir biji dimana lendir tersebut adalah inhibitor proses perkecambahan (Prasetya dkk., 2017). Penelitian Paciolla dkk., (2019) menyimpulkan bahwa benih dalam keadaan terlalu kering akan menghasilkan tanaman yang berbuah dengan kandungan vitamin $\mathrm{C}$ rendah. Saat pemanenan berlangsung (HST-45) musim mulai memasuki pancaroba atau transisi dan di akhir panen (HST-72) sudah musim kemarau. Musim kemarau menyebabkan cekaman kekeringan pada tanaman sehingga memicu mekanisme metabolisme pertahanan dengan cara membentuk metabolit sekunder (Manurung dkk., 2019). Penelitian ini mencatat bahwa masih terjadi hujan dengan intensitas yang rendah saat tanaman tomat mulai berbunga dan menghasilkan buah. Hadirnya hujan saat kemarau menjaga suplai air yang optimal, sehingga juga akan menginduksi ketersediaan kalsium sebagai penentu biosintesis asam askorbat (Renna dkk., 2019).

Penelitian ini juga memperoleh hasil bahwa intensitas cahaya sangat menentukan banyaknya vitamin $\mathrm{C}$ yang terkandung dalam buah tomat. Intensitas cahaya tertinggi terjadi di bulan maret sebesar 296 lux dan terendah di bulan juni hanya 9,0 lux. Korelasi yang terbentuk berbanding lurus dengan persentasi pengaruh sebesar 77,5\% (Gambar 2). Hal ini senada dengan hasil temuan Paciolla dkk., (2019) bahwa paparan cahaya yang tinggi dapat meningkatkan aktvitas enzim yang berperan dalam sintesis vitamin $\mathrm{C}$. Intensitas cahaya tinggi akan mempercepat laju fotosintesis sehingga memperbanyak terbentuknya karbohidrat yang menjadi bahan precursor pembentukan vitamin C (Ntagkas dkk., 2019). Kondisi ini menyebabkan terjadinya akumulasi vitamin $\mathrm{C}$ pada bagian tumbuhan yang berfungsi sebagai penyimpan karbohidrat salah satunya adalah buah
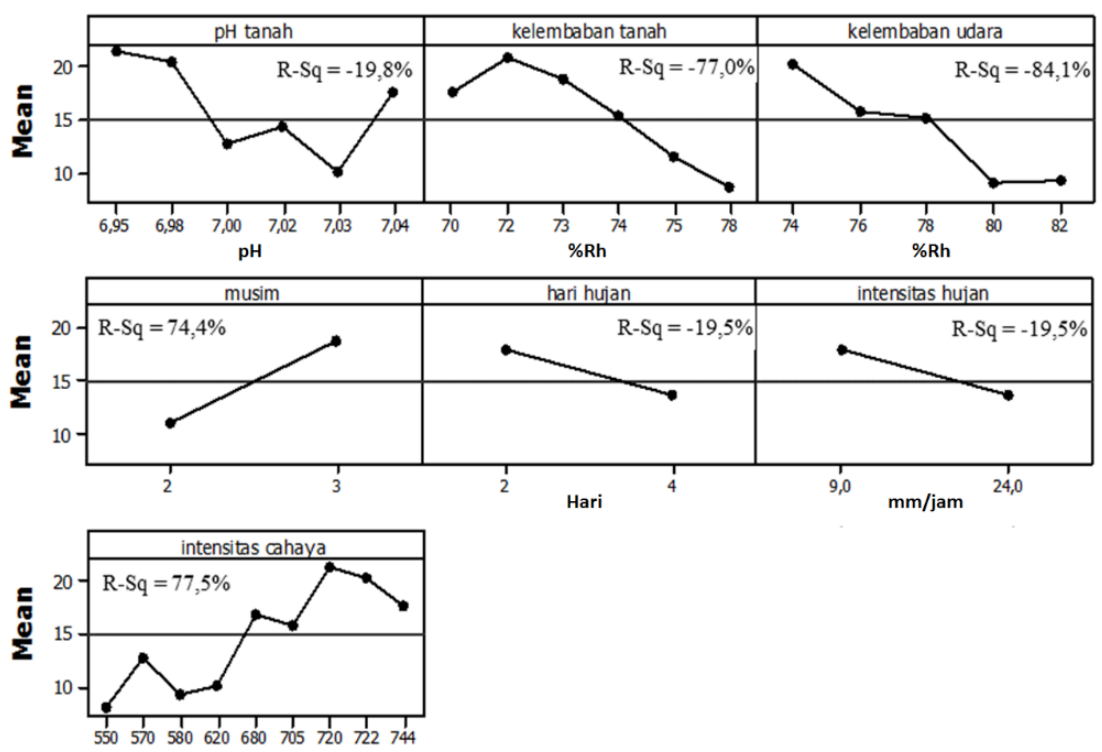

lux

Gambar 2. Hubungan kondisi iklim dengan kadar vitamin $\mathrm{C}$ pada buah tomat segar 
Paparan hasil dan analisis penelitian ini memberikan gambaran yang jelas waktu yang tepat untuk menanam dan memanen buah tomat varietas servo agar diperoleh kadar vitamin $\mathrm{C}$ yang optimal untuk dikonsumsi. Penanaman di akhir musim penghujan dan waktu panen di awal musim kemarau meningkatkan probabilitas mendapat vitamin $\mathrm{C}$ buah tomat yang tinggi. Apabila tomat yang dikonsumsi berasal dari HST-66 maka hanya diperlukan sekitar 4 buah tomat sehari untuk memenuhi angka kecukupan gizi per hari dari sumber vitamin $\mathrm{C}$ untuk orang dewasa.

Kadar vitamin $\mathrm{C}$ pada buah tomat segar varietas servo dipengaruhi oleh tingkat kematangan buah yang di hitung dari hari setelah tanam. Kandungan vitamin C optimal akan didapatkan jika panen dilakukan pada HST ke-57, 63, dan 66. Selain itu kondisi iklim dan lingkungan selama penanaman juga menentukan kandungan vitamin $\mathrm{C}$ pada buah. Asupan vitamin $\mathrm{C}$ terbaik dari konsumsi buah tomat diperoleh pada buah yang ditanaman pada akhir musim hujan dan dipanen saat awal musim kemarau serta dipaparkan pada intensitas cahaya yang cukup tinggi.

\section{KESIMPULAN}

Vitamin $\mathrm{C}$ buah tomat segar mencapai kadar optimum merespon proses pematangan dan kondisi iklim selama masa pertumbuhannya. Penanaman di akhir musim penghujan dan waktu panen di awal musim kemarau serta penempatan tumbuhan di bawah paparan sinar matahari yang maksimal meningkatkan probabilitas mendapat vitamin $\mathrm{C}$ buah tomat yang tinggi. Untuk mendapatkan asupan vitamin $\mathrm{C}$ terbaik dari konsumsi buah tomat segar, direkomendasikan agar buah tomat dipanen pada 63 hari setelah tanam yang menunjukkan puncak kadar vitamin $\mathrm{C}$.

\section{UCAPAN TERIMA KASIH}

Tim peneliti mengucapkan terimakasih kepada pihak yang telah banyak membantu diantaranya laboran pada laboratorium analisis makanan dan minuman, Fakultas Farmasi, Institut Ilmu Kesehatan Bhakti Wiyata Kediri, serta sentra budidaya tomat Dinas Pertanian, Kabupaten Jombang.

\section{DAFTAR PUSTAKA}

Asmara, A. P. (2016). Analysis of Vitamin C Level Contained in Mango Gadung (Mangifera indica L) with Varied Retension Time Elkawnie. Journal of Islamic Science and Technology; 2; 37-50.
Biancatelli, R. M. L. C., Berrill, M. \& Marik, P. E. (2020). The Antiviral Properties of Vitamin C. Expert Review of Anti-Infective Therapy; 18; 99101.

Bieniasz, M., Dziedzic, E. \& Kaczmarczyk, E. (2017). The Effect of Storage and Processing on Vitamin C Content in Japanese Quince Fruit. Folia Horticulturae; 29; 83-93.

Boretti, A. \& Banik, B. K. (2020). Intravenous Vitamin $\mathrm{C}$ for Reduction of Cytokines Storm in Acute Respiratory Distress Syndrome. Pharma Nutrition; 12; 100190.

BPS Kabupaten Kediri. (2018). Kabupaten Kediri Dalam Angka. Kediri: Badan Pusat Statistik Kabupaten Kediri.

Damayanti, E. T. \& Kurniawati, P. (2017). Perbandingan Metode Penentuan Vitamin C pada Minuman Kemasan Menggunakan Metode Spektrofotometer UV-Vis dan Iodimetri. Prosiding Seminar Nasional Kimia dan Pembelajarannya; 258-266.

Devi, Y. R., Mineshwor, P. \& Thokchom, R. (2016). Changes in Vitamin C Content During the Various Stages of Ripening of Citrus grandis-A Major Fruit Crop of Sikkim, India. The Bioscan; 11; 1461-1463.

Dewhirst, R. A. \& Fry, S. C. (2018). The Oxidation of Dehydroascorbic Acid and 2,3-diketogulonate by Distinct Reactive Oxygen Species. The Biochemical Journal; 475; 3451-3470.

Dobrin, A., Nedelus, A., Bujor, O., Mot, A., Zugravu, M. \& Badulescu, L. (2019). Nutritional Quality Parameters of the Fresh Red Tomato Varieties Cultivated in Organic System. Scientific Papers Series B Horticulture; 63; 439-443.

Duma, M., Alsina, I., Dubova, L. \& Erdberga, I. (2015). Chemical Composition of Tomatoes Depending on the Stage of Ripening. Chemical Technology; 66; 6-11.

El-Ishaq, A. \& Obirinakem, S. (2015). Effect of Temperature and Storage on Vitamin C Content in Fruits Juice. International Journal of Chemical and Biomolecular Science; 1; 17-21.

Ernest, E., Onyeka, O., A.C., O., \& R.O., O. (2017). Comparative Assessment of the Effect of Ripening Stage on the Vitamin C Contents of Selected Fruits Grown within Nsukka Axis of Enugu State. International Journal of Environment, Agriculture and Biotechnology; 2; 712-714. 
Fakhrunnisa, E., Kartika, J. \& Sudarsono. (2018). Produksi Tomat Cherry dan Tomat Beef dengan Sistem Hidroponik di Perusahaan Amazing Farm, Bandung. Buletin Agrohorti; 6; 316-325.

Fenech, M., Amaya, I., Valpuesta, V. \& Botella, M. A. (2019). Vitamin C Content in Fruits: Biosynthesis and Regulation. Frontiers in Plant Science; 9; 1-21.

Galani, J. H. Y., Patel, J. S., Patel, N. J. \& Talati, J. G. (2017). Storage of Fruits and Vegetables in Refrigerator Increases Their Phenolic Acids but Decreases the Total Phenolics, Anthocyanins and Vitamin C with Subsequent Loss of Their Antioxidant Capacity. Antioxidants; 6; 59.

Hapsari, R., Indradewa, D. \& Ambarwati, E. (2017). Pengaruh Pengurangan Jumlah Cabang dan Jumlah Buah terhadap Pertumbuhan dan Hasil Tomat (Solanum lycopersicum L.). Vegetalika; 6; 37.

Jones, R. B., Stefanelli, D. \& Tomkins, R. B. (2015). Pre-Harvest and Post-Harvest Factors Affecting Ascorbic Acid and Carotenoid Content in Fruits and Vegetables. Acta Horticulturae; 1106; 3141.

Manurung, H., Kustiawan, W., Wijaya Kusuma, I. \& Marjenah. (2019). Pengaruh Cekaman Kekeringan terhadap Pertumbuhan dan Kadar Flavonoid Total Tumbuhan Tabat Barito (Ficus deltoidea Jack). Jurnal Hortikultura Indonesia; $10 ; 55-62$.

Nemeskéri, E., Neményi, A., Bocs, A., Pék, Z. \& Helyes, L. (2019). Physiological Factors and Their Relationship with the Productivity of Processing Tomato Under Different Water Supplies. Water (Switzerland); 11; 586.

Ntagkas, N., Woltering, E., Bouras, S., De Vos, R. C., Dieleman, J. A., Nicole, C. C., Labrie, C. \& Marcelis, L. F. (2019). Light-Induced Vitamin C Accumulation in Tomato Fruits is Independent of Carbohydrate Availability. Plants; 8; 1-12.

Paciolla, C., Fortunato, S., Dipierro, N., Paradiso, A., De Leonardis, S., Mastropasqua, L. \& de Pinto, M. C. (2019). Vitamin C in Plants: From Functions to Biofortification. Antioxidants; 8; 1-26.

Pathy, K. (2018). Process for Preparation of Vitamin C and Method for Determination of Vitamin $\mathrm{C}$ in Tablets. Surgery \& Case Studies: Open Access Journal; 1; 1-14.
Pramono, A. A. (2016). Prinsip-prinsip Cerdas Usaha Pembibitan Tanaman Hutan. Jakarta: Penebar Swadaya.

Prasetya, W., Yulianah, I. \& Purnamaningsih, S. L. (2017). Pengaruh Teknik Ekstraksi dan Varietas Terhadap Viabilitas Benih Tomat (Lycopersicum esculentum L.). Jurnal Produksi Tanaman; 5; 257-264.

Rahman, N., Ofika, M. \& Said, I. (2015). Analisis Kadar Vitamin C Mangga Gadung (Mangifera SP) dan Mangga Golek (Mangifera indica L) Berdasarkan Tingkat Kematangan dengan Menggunakan Metode Iodimetri. Jurnal Akademika Kimia; 4; 33-37.

Renna, M., D’Imperio, M., Gonnella, M., Durante, M., Parente, A., Mita, G., Santamaria, P. \& Serio, F. (2019). Morphological and Chemical Profile of Three Tomato (Solanum lycopersicum L.) Landraces of A Semi-Arid Mediterranean Environment. Plants; 8; 273.

Risnayanti, R., Sabang, S. \& Ratman, R. (2015). Analisis Perbedaan Kadar Vitamin C Buah Naga Merah (Hylocereus polyrhizus) dan Buah Naga Putih (Hylocereus undatus) yang Tumbuh di Desa Kolono Kabupaten Morowali Provinsi Sulawesi Tengah. Jurnal Akademika Kimia; 4; 91-96.

Rosmainar, L., Ningsih, W., Ayu, N. P. \& Nanda, H. (2018). Penentuan Kadar Vitamin C Beberapa Jenis Cabai (Capsicum sp.) dengan Spektrofotometri Uv-Vis. Jurnal Kimia Riset; 3; 1-5.

Surbakti, E. S. B. \& Berawi, K. N. (2016). Tomat (Lycopersicum esculentum Mill) sebagai Anti Penuaan Kulit Tomato (Lycopersicum esculentum Mill) As Anti Aging Skin. Majority; 5; 73-78.

Susilo, A., Rumende, C. M., Pitoyo, C. W., Santoso, W. D., Yulianti, M., Herikurniawan, H., Sinto, R., Singh, G., Nainggolan, L., Nelwan, E. J., Chen, L. K., Widhani, A., Wijaya, E., Wicaksana, B., Maksum, M., Annisa, F., Jasirwan, C. O. \& Yunihastuti, E. (2020). Coronavirus Disease 2019: Tinjauan Literatur Terkini. Jurnal Penyakit Dalam Indonesia; 7; 45-67.

Tareen, H., Ahmed, S., Mengal, F., Masood, Z., Bibi, S. \& Mengal, R. (2015). Estimation of Vitamin C Content in Artificially Packed Juices of Two Commercially Attracted Companies in Relation to Their Significance for Human Health. 
Biological Forum - An International Journal; 7; 682-685.

Taufik, Y. (2015). Statistik Produksi Hortikultura Tahun 2014. Jakarta: Direktorat Jenderal Hortikultura, Kementerian Pertanian.

Valšíková-Frey, M., Komár, P. \& Rehuš, M. (2018). The Effect of Varieties and Degree of Ripeness to Vitamin C Content in Tomato Fruits. Acta Horticulturae et Regiotecturae; 20; 44-48.

Wei, J., Liu, G., Liu, D. \& Chen, Y. (2017). Influence of Irrigation During the Growth Stage on Yield and Quality in Mango (Mangifera indica L). PLoS One, 12; 1-14.
Zanini, D., Silva, M., Oliveira, E., Mazalli, M., Kamimura, E. \& Maldonado, R. (2018). Spectrophotometric Analysis of Vitamin C in Different Matrices Utilizing Pottasium Permanganate. European International Journal of Science and Technology; 7; 1-16.

Zhang, J. Y., Pan, D. L., Jia, Z. H., Wang, T., Wang, G. \& Guo, Z. R. (2018). Chlorophyll, Carotenoid and Vitamin C Metabolism Regulation in Actinidia chinensis "Hongyang" Outer Pericarp during Fruit Development. PLoS One; 13; 1-17. 